Журнал«Герспективита інновації науки

(Серія«Гедагогіка», Серія«ГЕихологія», Серія«Медицина»

№4(4) 2021

УДК $159.922 .763: 796.342: 371.83$.

https://doi.org/10.52058/2786-4952 -2021-4(4)-444-454

Ярошко Микола Михайлович кандидат психологічних наук, доцент кафедри педагогіки та психології, Приватна установа „Вищий навчальний заклад „Міжнародний гуманітарно-педагогічний інститут „Бейт-Хана”, пл. Успенська, 5Д, м. Дніпро, 49000, тел.: (056) 717-70-34, e-mail: petroy1@ukr.net, https://orcid.org/0000-0002-5387-759X

\title{
ПСИХОЛОГІЧНІ АСПЕКТИ РОЗВИТКУ ОСОБИСТІСНОӤ ІДЕНТИФІКАЦІЇ У ПІДЛІТКІВ ДЕВІАНТНОЇ ПОВЕДІНКИ ЧЕРЕЗ ІНТЕРАКТИВНІ ФОРМИ РОБОТИ У СПОРТИВНОМУ ПІДЛІТКОВОМУ КЛУБІ 3 НАСТІЛЬНОГО ТЕНІСУ
}

Анотація. У статті досліджено психологічні аспекти розвитку особистісної ідентифікації у підлітків девіантної поведінки, через інтерактивні форми роботи у процесі соціально-психологічної діяльності спортивного підліткового клубу. Розглянуто історичні передумови вивчення особистісної ідентифікації у парадигмах сучасної психології. 3'ясовано, що процес залучення підлітків 3 девіантною поведінкою до діяльності, через інтерактивні форми роботи у такому клубі $є$ своєрідною реакцією, формою соціально-психологічного захисту підлітків і молоді в період загальної особистісно-соціальної невизначеності. Відзначимо, що саме підлітковий спортивний клуб дає змогу нестримному потягу у реалізації себе в екстремальних ситуаціях і певним чином сприяє профілактиці впливу девіантної поведінки через інтерактивні форми роботи на процес їх особистісної ідентифікації. Розглядаються особливості розвитку особистісної ідентифікації у підлітків девіантної поведінки, через інтерактивні форми роботи у спортивному підлітковому клубі з настільного тенісу, рівень розвитку рефлексивності в залежності від їх соціально-психологічних характеристик. Визначено методологічні засади та розроблено концепцію дослідження проблеми профілактики та корекції девіантної поведінки підлітків, через інтерактивні форми роботи. У роботі також висвітлено, що саме психолого-педагогічний ефект впливу громадської думки колективу такого підліткового спортивного клубу на підростаючу особистість складається 3 низки усвідомлених i неусвідомлених актів, що полягає у засвоєнні членом клубу соціального досвіду, суспільних цінностей, норм поведінки під час його активної діяльності, через залучення до різноманітних інтерактивних форм роботи.

Ключові слова: ідентичність, підлітковий клуб, особистісна ідентифікація, девіантна поведінка, профілактично-корекційна робота. 
Yaroshko Mykola Myhailovych Candidate of Psychological Sciences, Associate Professor of Pedagogy and Psychology, Private Institution "Higher Educational Institution" International Humanitarian and Pedagogical Institute "Beithana", Sq. Uspenska, 5D, Dnipro, 49000, tel.: (056) 717-70-34, e-mail: petroy1@ukr.net, https://orcid.org/0000-0002-5387-759X

\section{PSYCHOLOGICAL ASPECTS OF THE DEVELOPMENT OF DEVIANT ADOLESCENTS' PERSONAL IDENTIFICATION THROUGH INTERACTIVE ACTIVITIES IN A SPORTS CLUB OF TABLE TENNIS}

Abstact. The article examines the psychological aspects of the development of personal identification in adolescents of deviant behavior, through interactive forms of work in the process of socio-psychological activities of the sports teen club. The historical preconditions for the study of personal identification in the paradigms of modern psychology are considered. It was found that the process of involving adolescents with deviant behavior in activities through interactive forms of work in such a club is a kind of reaction, a form of social and psychological protection of adolescents and youth in a period of general personal and social uncertainty. It should be noted that it is the teenage sports club that allows the uncontrollable urge to realize themselves in extreme situations and in some way helps to prevent the influence of deviant behavior through interactive activities on the process of their personal identification. Peculiarities of development of personal identification in adolescents of deviant behavior, through interactive forms of work in a teenage sports club of table tennis, the level of development of reflexivity depending on their socio-psychological characteristics are considered. Methodological bases are defined and the concept of research of a problem of prevention and correction of deviant behavior of teenagers, through interactive forms of work is developed. The paper also highlights that the psychological and pedagogical effect of public opinion of the sports club's staff on the growing personality consists of a number of conscious and unconscious acts, which means the assimilation of social experience, social values, norms of behavior during his active work. through involvement in various interactive forms of work.

Keywords: identity, teen club, personal identification, deviant behavior, preventive and corrective work.

Постанова проблеми. Демократичні перетворення, що відбуваються в сучасному суспільстві у зв'язку 3 розбудовою України як цивілізованої європейської держави, зумовлюють інтенсивний розвиток практичної психології та психологічної служби. Тому у психології і соціології поняття «ідентифікація» визначається як процес емоційного, когнітивного, оцінно-прогностичного та іншого само ототожнення особистості 3 іншою людино, групою, зразком. Необхідно відзначити, що у межах вітчизняної психології ідентифікація розглядається дослідниками у тісному взаємозв'язку з процесом виокремлення 
суб'єкта від оточення. Зауважимо, що на поведінковому рівні це знаходить вияв в амбівалентному ставленні суб'єкта до іншої людини.

Отже, особистісна ідентифікація полягає в емоційно-когнітивному ототожненні одного індивідуума з іншим, що відіграє важливу роль для обох «дійових осіб» навчально-виховної взаємодії. Саме тому психологу та соціальному педагогу особистісна ідентифікація допомагає «увійти» у внутрішній світ вихованців, відчути його у всій повноті, неповторності i розмаїтті, а вихованцю це допомагає асимілювати у своїй свідомості, психологічно «привласнити» найпривабливіші особистісні якості психолога, як старшого товариша, помічника, що виступає в якості носія професійного i життєвого досвіду, творчої діяльності.

Відзначимо, що з погляду теорії дане питання є складним, оскільки, поперше, торкається комплексного за своїм характером явища на стику соціології, соціальної психології, психіатрії, соціальної педагогіки та інших наук. По-друге, загальну теорію зміни особистісної ідентифікації вітчизняною наукою, по суті, не розроблено. Цій темі присвячені лише окремі дослідження, зокрема, характеризуючи особистісну ідентифікацію сучасних підлітків, дослідники (О. Захаров, М. Гаранян, І. Дубровіна, Г. Крайг, С. Колот, С. Максименко, В. Моргун, Н. Ньюкомб, А. Прихожан, Ф. Райс, С. Ракітянська, та ін..) зауважують певну розмитість, неоднозначність та асоціальність у трактуванні даного поняття, а також соціокультурну детермінованість, пов'язаність 3 негативною емоційністю.

Однак, у практичному плані корекція особистісної ідентифікації є складним психологічним і моральним феноменом, що залишає у житті підлітка глибокий слід, невід'ємний від душевних потрясінь.

Аналіз останніх досліджень і публікацій. Зауважимо, що представники вітчизняної психології (В. В. Абрамєнкова, Л.С. Виготський, Л.В.Клочек, О. М. Леонтьєв, А.А. Налчаджян, Л.Ф. Обухова, Н. В. Скотна тощо) розглядали ідентифікацію дитини зі значущими дорослими, обмежуючись дослідженнями іiі прояву у свідомій сфері психіки та нівелюючи при цьому глибинно-психологічні детермінанти.

На думку К.О. Черемних, поряд 3 поняттям «ідентифікація» важливе місце відводиться поняттю «особистісна ідентифікація», що $є$ природнім процесом формування особистості. Особистісна ідентифікація є надзвичайно важливою для нормального інтелектуального $\mathrm{i}$ фізичного розвитку людини, $€$ найгострішим механізмом засвоєння міжособистісного досвіду взаємодії, а також основою набуття досвіду в будь-якій сфері життя, а без такого досвіду неможлива активна адаптація до навколишнього середовища. Дослідник вважає, що особистісна ідентифікація - розуміння іншої людини шляхом ототожнення себе з нею. Тому механізм цей починає працювати досить рано, і перший об'єкт, 3 яким ідентифікує себе дитина, - це батьки. Отже, особистісна ідентифікація $є$ важливою для нормального психічного розвитку людини на всіх вікових етапах, 
але особливо у підлітковому та юнацькому віці (з однолітками, літературними героями тощо). Зазначимо, що серед питань, які входять у широку проблему особистісної ідентифікації підростаючої особистості, мабуть, одним 3 найскладніших $є$ питання корекції особистісної ідентичності девіантного підлітка через інтерактивні форми роботи у підлітковому клубі. Тому розв'язання проблеми розвитку міжособистісної ідентифікації у підлітковому віці, іiі корекції на емоційному та поведінковому рівні є актуальним, особливо якщо це стосується підліткової девіантної поведінки.

Мета статті - обгрунтувати психологічні аспекти розвитку особистісної ідентифікації у підлітків девіантної поведінки через інтерактивні форми роботи в процесі соціально-психологічної діяльності підліткового спортивного клубу.

Виклад основного матеріалу. На сучасному етапі розбудови нової української школи ситуація зміни соціальної та культурної ідентичності особистості дає змогу розкрити складні психологічні процеси, які тісно пов'язані 3 розломом свідомості, зміною життєвих цілей та пріоритетів, а також перебудовою найглибших психологічних структур. Це пояснює актуальність проблеми підвищення якості профілактики та корекції девіантної поведінки підлітків. Проблема надання психологічної допомоги людині передбачає пізнання цілісної психіки особистості в їі свідомих та несвідомих виявах. Такий підхід орієнтує психологічну практику на розкриття індивідуальної неповторності психіки суб'єкта та дослідження глибинно-психологічних механізмів, серед яких вагоме місце посідають феномени ідентифікації та особистісної ідентифікації. Однак, як ми бачимо, відправним моментом у дослідженні зміни особистістю будь-якої своєї ідентичності є більш загальною проблемою стійкості та змінюваності підростаючої особистості. Протягом життя особистість часто переосмислює особистісні цінності, змінює політичні, ідеологічні орієнтири, моральні критерії. Це говорить про те, що навіть у межах одних цінностей особистість з часом змінює акценти та пріоритети, i, таким чином, постає перед нами у зовсім іншому світі, демонструючи вже відмінну соціальну поведінку, ставлення до світу, до свого оточення. Саме тому сталість особистості виявляється у постійному відновленні на різних етапах свого життя вектора їі розвитку.

Зауважимо, що досліджуючи вплив девіантної поведінки на процес особистісної ідентифікації, необхідно звернути особливу увагу на те, що їх цілком можна розглядати як одну із базових інтегративних основ у процесі профілактики девіантної поведінки підлітка через інтерактивні форми роботи, які дають змогу своєчасно діагностувати, виявляти і педагогічно доцільно впливати на стосунки у спортивному підлітковому клубі 3 настільного тенісу, що створений на базі Дрогобицької дитячої юнацької спортивної школи імені Івана Боберського, на розвиток різноманітних ініціатив, формування ціннісних орієнтацій підростаючої особистості, їі ставлення до себе, свого фізичного i морального здоров'я, до оточуючого середовища. Отже, актуальною постає 
Журнал«Герспективи та інновації науки

(Серія«Гедагогіка», Серія «Геихологія», Серія «Медицин»

№4(4) 2021

проблема комплексного психолого-педагогічного вивчення, узагальнення i осмислення сутності профілактично-корекційної роботи спортивного підліткового клубу, їхнього місця і ролі в процесі психолого-педагогічного впливу на профілактику та корекцію девіантної поведінки підлітків, через інтерактивні форми роботи. Нами напрацьований достатньо цікавий досвід організації i проведення різноманітних клубних форм роботи щодо підвищення особистісної ідентифікації підлітків девіантної поведінки, які вступають у конфлікт із законом.

Негативний вплив девіантної поведінки на процес особистісної ідентифікації найбільш інтенсивно відбувається у підлітковому віці. Саме цей період $\epsilon$ особливо важливим і завершальним у формуванні основних засад особистості, які ведуть людину до самовизначення у всіх сферах життєдіяльності. Вплив девіантної поведінки на характер протікання процесів ідентифікації може також негативно позначитися на становленні у підлітків особистісної ідентифікації, яка визначає шлях подальшого їх розвитку.

Нині вже не викликає сумнівів той факт, що досліджувати соціальнопсихологічну діяльність спортивного підліткового клубу з настільного тенісу, використовуючи для цього тільки напрацьовані в теоретико-методологічному плані зміст, форми, методи і засоби соціально-психологічної роботи 3 девіантними підлітками через інтерактивні форми роботи, $\epsilon$ неможливо. Зауважимо, що з усією гостротою постає проблема розробки принципово нових підходів до вивчення діяльності спортивного підліткового клубу з настільного тенісу, а також його понятійного апарату. Дослідження соціально-психологічної діяльності сучасних підліткових клубів за інтересами, які проводилися в Україні дають підстави вважати, що участь підлітків і молоді у зазначеній діяльності допомагає їм віднайти, зокрема, через інтерактивні форми роботи найоптимальніші шляхи і засоби розв'язання вказаних проблем.

3 вище сказаного випливає, що процес залучення підлітків 3 девіантною поведінкою до діяльності у підлітковому спортивному клубі через різноманітні інтерактивні форми роботи є реакцією, а також своєрідною формою соціальнопсихологічного захисту підлітків i молоді в період загальної особистісносоціальної невизначеності. Звідси випливає, що саме підлітковий спортивний клуб з настільного тенісу дає змогу реалізуватися нестримному потягу підлітків до романтики, фізичного розвитку, до бажання випробувати самого себе в екстремальних ситуаціях і певним чином сприяє профілактиці впливу девіантної поведінки на процес їх особистісної ідентифікації. Отже, власне кажучи,це i визначає сутність діяльності переважної більшості спортивних підліткових клубів, які за своєю психолого-педагогічною характеристикою є, по суті, тією ж неформальною групою ровесників; разом 3 тим вони, не втрачаючи своєї психологічної, сутнісної привабливості для підлітків, $\epsilon$ також чітко структурованою, дисциплінованою, з метою, формами і засобами соціалізації i 
психолого-педагогічного впливу організацією. Тобто, це $є$ у певній мірі «приручений» суспільством мікро соціум, який 3 метою самореалізації, саморозвитку, самоактуалізації, саморегуляції та самовиховання створює необхідні сприятливі умови для активізації особистісного розвитку членів спортивного підліткового клубу, що активно сприяє формуванню у них особистісної ідентифікації.

У результаті проведених нами психолого-педагогічних досліджень ми дійшли висновку, що застосування відповідно сконструйованої моделі побудови соціально-психологічної діяльності спортивного підліткового клубу 3 настільного тенісу дасть можливість не лише осмислити сутність процесу розвитку ціннісних орієнтацій у вихованців, а й створити механізм формування суспільно вартісних орієнтацій, домогтись позитивно спрямованої соціалізації девіантних підлітків, через залучення їх до різноманітних інтерактивних форм роботи.

В експериментальному дослідженні нами були використані такі методи: соціометрія, тест незакінчених речень (модифікований нами відповідно завданням дослідження), проективні методики, стандартизовані інтерв'ю, вивчення продуктів діяльності неповнолітніх, аналіз документації.

Інтерактивні форми роботи, які проводилися нами, були спрямовані на зниження кількості правопорушень у підлітків девіантної поведінки, так як попередні дослідження показали, що різні соціально-психологічні відмінності між середовищем, в якому знаходиться підліток і школою, підлітковим клубом призводять до того, що такий підліток часто знову скоює нові правопорушення, ще так і не зумівши скоректувати ранні відхилення у своїй поведінці.

У процесі планування профілактично-корекційної клубної програми, ми виділили низку переваг, які нам необхідно було використати у роботі 3 підлітками девіантної поведінки. В процесі нашого дослідження ми виходили 3 жорстокого розподілу ролей в умовах підліткового спортивного клубу, а також 3 того, що у ньому також є достатньо серйозна небезпека бути або стати менш значним в очах референтної групи. Тому можна було передбачити, що у підлітковому спортивному клубі підлітки девіантної поведінки також можуть активно включатися у різноманітні клубні форми роботи. Це передбачення було підтверджено досвідом роботи тренеріввикладачів Дрогобицької дитячої юнацької спортивної школи, на базі якої і був створений підлітковий спортивний клуб. Це підняло рівень мотивації щодо набуття психологічних знань, як у підлітків девіантної поведінки, так i y працівників підліткового спортивного клубу, тренерів-викладачів дитячої юнацької спортивної школи настільки, що вони побачили можливість самоствердитись у середовищі своїх ровесників. Така діяльність пояснюється двома причинами:

- участь у різноманітних інтерактивних формах роботи розглядується підлітками девіантної поведінки, як можливість виявлення своїх інтересів, 
Журнал«Герспективитаінновації науки»

(Серія«Гедагогіка», Серія«Гцихологія», Серія«Медицинв»

№4(4) 2021

розвитку здібностей $\mathrm{i}$ адаптація до суспільного середовища через клубні форми роботи, які проводять з ними самі ж наставники підліткового спортивного клубу;

- участь підлітків девіантної поведінки у клубних формах роботи разом із своїми наставниками сприяє самоствердженні їх як особистості в очах своїх вихователів і вчителів та прилученні підлітків девіантної поведінки до спілкування 3 своїми наставниками - тренерами 3 різноманітних видів спорту, що передбачає їх здатність щодо вирішення їхніх життєвих проблем [7].

Наш підлітковий клуб "Каменяр" поставив перед собою досить складну, але разом з тим і цікаву мету: організувати такі різноманітні інтерактивні форми роботи, які допомогли б підліткам девіантної поведінки скорегувати певні відхилення у їхній поведінці.

Поставлена мета визначила наступні задачі:

- сформувати у підлітків девіантної поведінки мотивацію участі у різноманітних клубних формах роботи;

- розробити методику проведення занять, яка заохочувала б підлітків девіантної поведінки до саморозкриття у роботі 3 своїми наставниками.

- відпрацьовувати такі підходи психотерапевтичного впливу під час проведення різноманітних клубних форм роботи, які б сприяли корекції відхилень у їхнй поведінці та допомогли б вирішити проблему порушення їх особистісної ідентифікації.

Розв'язання таких задач передбачало знання психологічних особливостей розвитку особистісної ідентифікації у підлітків девіантної поведінки, розуміння того, що перебування у негативній групі підлітків накладає на психіку підлітка незгладженні відбитки (тим більше це стосується ще не достатньо сформованої психіки). Таким підліткам девіантної поведінки, на нашу думку, необхідна систематична психологічна допомога, яка дозволила б призупинити деструктивні процеси розвитку психіки до того, як вони стануть незворотними $[3 ; 5 ; 6]$.

В процесі нашого дослідження ми розглядали всі можливі шляхи підвищення у підлітків девіантної поведінки мотивації до самоствердження своєї особистості, через включення їх у різноманітні інтерактивні форми роботи. Основним новоутворення цього періоду - почуття дорослості, говорячи іншими словами, такий підліток постійно шукає підтвердження тому, що він вже $\epsilon$ дорослий. Основними компонентами почуття дорослості виступає престижність здійснюваної діяльності, і тому нам необхідно було зробити участь у різноманітних інтерактивних формах роботи престижним для такої категорії підлітків. Як показала попередня бесіда наставників підліткового спортивного клубу, для багатьох підлітків девіантної поведінки пріоритетним виступає приєднання до ділового світу, спортивних секцій, технічних гуртків, творчих 
(музичних) груп. Необхідно відмітити прагнення підлітків девіантної поведінки до неформальних об`єднань, так званий «юнацький конформізм»: такому підлітку необхідно приналежати до будь-якої із соціальних груп, він хоче відчути себе приєднаним до певної структури. Отже тим і пояснюється тяжіння підлітків девіантної поведінки до кримінальних угрупувань 3 жорстко структурованими відносинами. В ході проведення клубних форм занять підлітковий спортивний клуб виступив для підлітків девіантної поведінки міні об'єднанням зі всіма своїми правилами, законами і традиціями. Для підвищення престижності роботи у підлітковому спортивному клубі, а також для зниження тривожності викликаної офіційним статусом підліткового спортивного клубу, ми запропонували назвати підлітковий спортивний клуб «Соціально-психологічним клубом», а клубні форми занять - тренінговими заняттями «Соціальнопсихологічного клубу». В процесі проведення занять, дуже швидко підлітки девіантної поведінки, які приймали активну участь у клубних формах роботи стали розповідати своїм ровесникам, 3 якими вони спілкувалися про те, що у «Соціально-психологічному клубі» можна почувати себе краще, ніж у школі чи навіть у колі сім'ї [4; 7].

Підтримування інтересу в процесі проведення клубних форм роботи досягалося зміною форм діяльності протягом кожного дня проведених занять. Рухливі спортивні заняття у секціях 3 дзюдо, тек Вандо змінювали дискусії, мозкові штурми, КВК, дискотеки, арт-терапія, інформування - розв'язання психологічних задач. Однак, найбільш важливою для підвищення мотивації щодо корекції відхилень у поведінці підлітків девіантної поведінки, на наш погляд, була модель відносин, яка складалась в самому «Соціальнопсихологічному клубі». Відомий київський психолог Н. Максимова вважає, що основна причина формування соціально-дезадаптованої поведінки підлітка фрустрація трьох основних соціальних потреб: у самоповазі; у визнанні значимими дорослими; у визнанні ровесниками [2; 7].

Не маючи можливості реалізувати ці три життєво важливі потреби, підліток девіантної поведінки починає відчувати труднощі під час реалізації самого себе, а також свою неспроможність і неможливість вирішити проблеми, 3 якими він стикається. Перед підлітком девіантної поведінки виникає дилема: або йому необхідно визнати, що поганий $є$ він сам, i тому «добре» суспільство до нього погано ставиться; або навпаки. Це $\epsilon$ причиною неадекватного ставлення підлітка девіантної поведінки до оточуючих, однак в силу особистісної незрілості, такий підліток ще не в стані скористатися всім цим арсеналом психологічного захисту і тому звертається до найпростіших їх форм - агресивної поведінки.

Самоповагу у підлітків девіантної поведінки, юнаків можна сформувати через залучення їх у такі види клубних форм роботи, в яких вони можуть досягнути значного успіху. В нашому випадку це вдале (максимально наближене до життя) програвання ситуацій, розбір психологічних задач, конструктивний 
Журнал«Герспектвиитаіноовації наукиљ

(Серія«Гедагогіка», Серія«Гцихологія», Серія«Медицинв»

№4(4) 2021

вихід 3 конфлікту, побудова гармонійних відносин та ін. [7].

Виступаючи значимими дорослими в очах підлітків девіантної поведінки, наставники соціально-психологічного підліткового клубу звертають їх увагу на успішність виконання окремих видів діяльності, заохочують захопленість або підтримують їх у періоди невдач. Потреба у повазі значимими дорослими задовольнялась завдяки доброзичливому, емоційно теплому ставленні до підлітка девіантної поведінки зі сторони їх наставників. Найголовніше як для наставників соціально- психологічного підліткового клубу, так і для вчителів школи побачити у кожного із підлітків девіантної поведінки індивідуальність. Сприятливий психологічний клімат, просте людське розуміння - це те, чого так не вистачає підліткам девіантної поведінки, а віра в те, що вони реально здатні побудувати сприятливе майбутнє, може підтримати їх і стати для них дороговказом у важкі хвилини їхнього життя. Саме тут в умовах соціальнопсихологічного підліткового клубу в переважній більшості емоційна взаємодія вирішує набагато більше, ніж застосування оголених технік.

Підлітки девіантної поведінки часто стають на шлях скоєння злочинів через те, що близькі їм люди їх не люблять і недовіряють їм. Довіра і любов - це не тільки емоційне тепло, турбота, але i увага, розуміння i прийняття їх такими, якими вони $\epsilon$. Тому, як нам видається, в основу клубних форм роботи 3 підлітками девіантної поведінки повинна бути покладена ідея прийняття їх такими, якими вони є насправді.

Доброзичливе ставлення до них 3 боку наставників соціальнопсихологічного підліткового клубу сприяє самоствердженню їх в очах своїх ровесників.

Досягнення наступної задачі (розробити методику проведення клубних форм роботи, яка б заохочувала підлітків девіантної поведінки до самореалізації їхніх інтересів і здібностей) здійснювалася нами в процесі забезпечення максимально комфортного психологічного клімату у соціальнопсихологічному клубі з врахування їх інтересів, нахилів та завдатків [6].

Особистісні особливості підлітків девіантної поведінки, а саме: низький рівень довіри до оточуючих, підлітково-юнацький максималізм, агресивне відстоювання свого психологічного простору, спонукали нас ввести внутрішньо групове саморозкриття поетапно. Звичайно, що кожен із підлітків девіантної поведінки, рівень довіри у яких був досить низький ще до того, як він прийшов у соціально-психологічний підлітковий клуб, то. звичайно, що він не буде відкриватися своїми думками 3 оточуючими його людьми, навіть тоді, коли він зустрінеться 3 психологом.

Таким чином, актуальність психологічного дослідження процесу розвитку у підлітків девіантної поведінки особистісної ідентифікації, зумовлена необхідністю розкриття психологічних механізмів виховних впливів, спрямованих на такої категорії підлітків під час їх перебування у підлітковому клубі. 
Висновки. Система профілактично- корекційної роботи 3 підлітками девіантної поведінки у соціально- психологічному підлітковому клубі відповідає вимогам щодо формування їх повноцінної особистості. Залучення підлітків девіантної поведінки до різноманітних інтерактивних форм роботи у соціальнопсихологічному підлітковому клубі сприяє розвитку у них особистісної ідентифікації.

Психологи, педагоги, тренери-викладачі повинні вбачати в дитячих та підліткових спортивних клубах великі потенційні можливості у формуванні підростаючої особистості й вимагати їх створення у кожному мікрорайоні міста, тому що ці виховні спортивні заклади є єдиною формою активізації спортивної діяльності дітей та підлітків через які вони мають можливість долучатися до міжособистісної комунікації та спілкування з ровесниками, що звільнить їх закріпачений розум, принижений дух, відволікатиме таких дітей від негативного впливу вулиці.

Організація профілактично-корекційної роботи, через залучення підлітків девіантної поведінки до різноманітних інтерактивних форм роботи забезпечує відчуття ними своєї гідності, самостійності, психологічної захищеності, що $є$ умовою підвищення у них особистісної ідентифікації та повернення їх до дотримання соціально прийнятих норм поведінки [5; 6].

Найголовніша функція спортивного клубу полягає також і в тому, що знайти такі види спортивної діяльності, такі спортивні секції, де дитина чи підліток зміг би стати справжнім творцем.

Головна мета діяльності сучасних спортивних підліткових клубів як одного із типів позашкільних навчальних закладів - створення оптимальних умов для інтелектуального розвитку, задоволення інтересів, нахилів вихованців, професійного самовизначення у майбутній спортивній діяльності, організації розумного дозвілля, відпочинку.

\section{Лimepamypa:}

1. Державна національна програма «Освіта (Україна XXI століття)». - К.: Райдуга. 1994. - C. 27.

2. Максимова Н.Ю. Формирование адекватной самооценки как условие профилактики нарушений в поведении учащихся. (Психологическая профилактика недисциплинированного поведения учащихся). - Киев, 1999 p.

3. Отклоняющееся поведение молодежи. Краткий словарь-справочник. Под ред. В.А.Попова, С.А. Завратина. Владимир, 1994. 144 с.

4. Подмазін С.I. Особистісно орієнтована освіта(соціально-філософський аналіз): Дис. Д-ра філософ.наук:09.00.03/Подмазін Сергій Іванович.-Дніпропетровськ, 2006.- 418 с.

5. Проколиенко Л. Н., Татенко В. А. Психологическая профилактика недисциплинированного поведении учащихся. К. 1999.

6. Татенко В.А. Трудный подросток: причины и следствия. - К., 1995.

7. Черемних К.О. Особистісне ототожнення як механізм самоздійснення й життєтворчості / К.О Черемних // Педагогіка і психологія: Науково теоретичний та інформаційний журнал АПН України, 2009. - №2, - С. 80-86. 
8. Щерба С. П., Курганов С. І., Перцова Л. В. Социально-негативные явления в ВТК и борьба с ними. - М., 1995.

9. Ярошко М. Психологія важковиховуваних підлітків. - Дрогобич : «Коло», 2002.

\section{References:}

1. Derzhavna natsionalna prohrama «Osvita (Ukraina XXI stolittia)» (1994). K.: Raiduha [in Ukrainian].

2. Maksymova N.Iu. (1999). Formyrovanye adekvatnoi samootsenky kak uslovye profylaktyky narushenyi v povedenyy uchashchykhsia. (Psykholohycheskaia profylaktyka nedystsyplynyrovannoho povedenyia uchashchykhsia). [Formation of adequate self-esteem as a condition for prevention of disorders in students' behavior. (Psychological prevention of undisciplined behavior of students)]. Kyiv: Vydavnytstvo «Osvita» [in Russian].

3. Otkloniaiushcheesia povedenye molodezhy. Kratkyi slovar-spravochnyk. [Deviant behavior of young people. A short dictionary-reference] (1994). Pod red. V.A.Popova, S.A.Zavratyna. Vladymyr: Vydavnytstvo Hosudarstvennoe obrazovatelnoe uchrezhdenye vыssheho professyonalnoho obrazovanyia «Vladymyrskyi hosudarstvennыi unyversytet ymeny Aleksandra Hryhorevycha y Nykolaia Hryhorevycha Stoletovыkh» [in Russian].

4. Podmazin S.I. (2006). Osobystisno oriientovana osvita (sotsialno-filosofskyi analiz) Personally oriented education (socio-philosophical analysis): Doctor's thesis. Dnipropetrovsk: Vydavnytstvo «Dnipro» [in Ukrainian].

5. Prokolyenko L. N., Tatenko V. A. (1999). Psykholohycheskaia profylaktyka nedystsyplynyrovannoho povedeny uchashchykhsia [Psychological prevention of undisciplined behavior of students]. K: Vydavnytstvo «Osvita» [in Russian].

6. Tatenko V.A. Trudnыi podrostok: prychynы y sledstvyia [Difficult teenager: causes and consequences]. K.: Vydavnytstvo «Osvita» [in Russian].

7. Cheremnykh K.O. (2009). Osobystisne ototozhnennia yak mekhanizm samozdiisnennia y zhyttietvorchosti [Personal identification as a mechanism of self-realization and life-creation. Pedahohika i psykholohiia : Naukovo teoretychnyi ta informatsiinyi zhurnal APN Ukrainy: Vydavnytstvo «Osvita», 2, 80-86 [in Ukrainian].

8. Shcherba S. P., Kurhanov S. I., Pertsova L. V. (1995). Sotsyalno-nehatyvnыe yavlenyia v VTK y borba s nymy [Socially negative phenomena in VTK and struggle against them]. M.: Vydavnytstvo «Znanye» [in Russian].

9. Yaroshko M. (2002). Psykholohiia vazhkovykhovuvanykh pidlitkiv [Psychology of difficult adolescents]. Drohobych : «Kolo» [in Ukrainian]. 